\title{
Deficit Irrigation and Split N Fertilization on Wheat and Barley Yields in a Semi-Arid Mediterranean Area
}

\author{
C.G. Abourached ${ }^{\S}$, S.K. Yau*, M.N. Nimah and I.I. Bashour \\ Faculty of Agricultural and Food Sciences, American Univ. of Beirut, Beirut, Lebanon \\ ${ }^{\S}$ Present address: Biological and Ecological Engineering Department, Oregon State University, Corvallis, OR 97331, \\ USA
}

\begin{abstract}
This study investigated the interactive effects of different rates of deficit irrigation and timings of $\mathrm{N}$ application on wheat and barley yields since there was no report on this important subject. Field experiments in strip-plot designs using sprinkler line sources were conducted for two years at a semi-arid Mediterranean site. The experiments consisted of 4 and 7 irrigation levels with 3 and $6 \mathrm{~N}$ treatments in 4 replicates in 2002-03 and 2003-04, respectively. In both years, there was a significant irrigation-by-N interaction on wheat grain yield but not on barley. In 2003-04, N application at stem elongation and heading produced the highest wheat grain yield at the four higher irrigation levels, but highest yield was obtained when $\mathrm{N}$ was applied at sowing and tillering at the two lowest irrigation levels. Nitrogen application at stem elongation and heading also gave the highest grain $\mathrm{N}$ content. The existence of interaction due to irrigation-by-timing of $\mathrm{N}$ application in wheat but not in barley could be because wheat has a higher $\mathrm{N}$ uptake after anthesis but lower nitrogen remobilization efficiency than barley. Results suggested that wheat farmers better apply $\mathrm{N}$ at stem elongation and heading for a higher yield and grain $\mathrm{N}$ content unless they are not irrigating or irrigate with minimum amount of water.
\end{abstract}

Keywords: Sprinkler line source, supplemental irrigation, timing of $\mathrm{N}$ application.

\section{INTRODUCTION}

In West Asia and North Africa, water shortage is the major constraint to agricultural production, and yields are generally low and variable due to inadequate and erratic seasonal rainfall. Barley (Hordeum vulgare L.) is the dominant crop in arid areas and wheat, both bread wheat (Triticum aestivum L.) and durum wheat (T. turgidum L. sub sp. $d u$ rum), predominant in the semi-arid areas. Traditionally, farmers tend to irrigate wheat but grow barley rainfed, as they receive higher revenue from wheat and barley is more adapted to dryland conditions. As irrigation is getting more common, farmers tend to put more irrigation to wheat than on barley.

Supplemental irrigation is expected to bring increased productivity and yield stability in a more sustainable manner on the vast areas of rain-fed land. Supplemental irrigation is defined as a technique used where a crop can be grown by natural rainfall alone but providing additional water by irrigation stabilizes and improves yield [1-2]. Supplemental irrigation significantly increased wheat yields in West Asia and North Africa, like in Syria [3], Lebanon [4], and Turkey [5], and near-maximum yields were obtained by $2 / 3$ [6] or $1 / 3$ [5] full supplemental irrigation. However, the excessive use of groundwater for supplemental irrigation seriously threatens the sustainability of groundwater availability, thus the need for improving water-use efficiency and sustainable use of water resources is clearly urgent.

*Address correspondence to this author at the Faculty of Agricultural and Food Sciences, American Univ. of Beirut, Beirut, Lebanon;

E-mail: sy00@aub.edu.lb
Regulated, deficit irrigation provides a means of reducing water consumption while minimizing adverse effects on yield [7]. By deficit irrigation, crops are deliberately under irrigated during plant growth stages that are relatively insensitive to water stress [8-9]. Optimum crop yields under deficit irrigation practices can be obtained by allowing a certain level of yield reduction of a given crop or area in order to divert the saved water to irrigate other areas or crops.

After drought, $\mathrm{N}$ supply is the major constraint in cereal farming within the Mediterranean area [10]. Soils in the Mediterranean region are generally low in organic matter and invariably low in mineral $\mathrm{N}$ [11]. In wheat, $\mathrm{N}$ promotes tiller production and survival [12], and increases kernel numbers per spike and grain yield [13-14]. However, the response of yield to $\mathrm{N}$ supply is strongly influenced by environmental conditions, especially the quantity and timing of water available to the crop [15]. However, increased $\mathrm{N}$ fertilizer rates often raise wheat yield up to a point, beyond which there is no additional response but greater $\mathrm{N}$ loss. Thus, an understanding of the interactive effects of $\mathrm{N}$ and water on yield is important to produce consistent and economically attractive yield increases [3].

Besides $\mathrm{N}$ rates, the timing of $\mathrm{N}$ application has an important effect on seed yield. The response to $\mathrm{N}$ fertilizer is maximized with $\mathrm{N}$ application just prior to onset of stem elongation when crop $\mathrm{N}$ demand is the greatest [16]. In West Asia and North Africa, split $\mathrm{N}$ application in the fall and in early spring is a common practice to reduce $\mathrm{N}$ loss and increase crop yield. In wheat, recovery of $\mathrm{N}$ fertilizer can be significantly increased by applying $\mathrm{N}$ at the beginning of stem elongation instead of at sowing [17]. In fact, maximum efficiency may be obtained with later application of $\mathrm{N}$ to 
avoid unnecessary vegetative growth, risk of lodging, denitrification, volatization, and runoff since active roots ensure swift $\mathrm{N}$ uptake [18].

In this study, the interactive effects of different rates of deficit irrigation and timings of $\mathrm{N}$ application on wheat and barley yields were investigated, since no studies had been reported on this important subject.

\section{MATERIALS AND METHODS}

\section{Site and Weather Information}

Field experiments were conducted for two years (200203 and 2003-04) at the Agricultural Research and Education Center $\left(33^{\circ} 56^{\prime} \mathrm{N}, 36^{\circ} 05^{\prime} \mathrm{E}, 995 \mathrm{~m}\right.$ a.s.1.) of the American University of Beirut in the semi-arid northern Bekaa Valley of Lebanon. The soil is an alkaline, clayey, Vertic Xerochrept formed from fine textured alluvium derived from limestone [19]. A different field was used in each year.

The long-term annual precipitation of the site is $513 \mathrm{~mm}$, $58 \%$ of which falls in December, January and February. The long-term mean annual temperature is $13.9{ }^{\circ} \mathrm{C}$. The frost-free period lasts from mid-April to mid-November. In 2002-03, although precipitation was unusually high $(928 \mathrm{~mm})$, distribution was poor. Precipitation more than twice the long-term average was received in December, February, and March, but below average rainfall was received in April and no rainfall was received in May. April and May were also warmer than the long-term average. In 2003-04, 581 mm of precipitation was received: higher than the average in January and February, but lower than the average in March to May. Mean temperature in March was warmer than the average.

\section{Irrigation}

One experiment on wheat and one on barley were carried out in each of 2002-03 and 2003-04. There were two factors: irrigation and $\mathrm{N}$, in each experiment, which was planted in a strip-plot design with 4 replications.

For irrigation, a sprinkler line source was used [20]. Under this system, irrigation water was delivered at a maximum rate near the line source and this rate decreased gradually as the distance increased from the line source. In 2002-03, the sprinkler line source was located in the middle of the field dividing the wheat and barley plots. The line source had 8 sprinklers with $4.4 \mathrm{~mm} \times 2.4 \mathrm{~mm}$ nozzles. The riser height was $50 \mathrm{~cm}$ and its diameter was $19 \mathrm{~mm}$. The operating pressure was 3.5 bars, and the radius of throw was $11 \mathrm{~m}$. There were 4 irrigation treatments: $\mathrm{ID}_{2}, \mathrm{ID}_{6}, \mathrm{ID}_{10}$ and $\mathrm{ID}_{12}$, i.e., measurements were taken at a distance of 2, 6, 10 and $12 \mathrm{~m}$ from the irrigation line source, respectively. Two irrigations were applied: the first one on 29th April (jointing stage) for 8 hours, and the second one only to wheat on 16th May (heading stage) for 6 hours.

In 2003-04, 2 lines sources spaced $48 \mathrm{~m}$ apart were used. One line source was placed in the middle of the wheat plots, and the other one was in the middle of the barley plots. Each irrigation line had 14 sprinklers. There were 7 irrigation treatments: $\mathrm{ID}_{1}, \mathrm{ID}_{3}, \mathrm{ID}_{5}, \mathrm{ID}_{7}, \mathrm{ID}_{9}, \mathrm{ID}_{11}$ and $\mathrm{ID}_{20}$, i.e., measurements were taken at a distance of $1,3,5,7,9,11$, and 20 $\mathrm{m}$ from the irrigation line source, respectively. Rain gauges were fixed on sticks at the crop height to measure the depth of the irrigation water applied. Seven 3-5 hr irrigations were carried out weekly from April 7 (stem elongation) to May 18 (heading). The irrigation amounts received by the treatments $\mathrm{ID}_{1}$ and $\mathrm{ID}_{3}$ were $>100 \%$ of evapo-transpiration (Table $\mathbf{1}$ ).

\section{Nitrogen Application}

Regarding $\mathrm{N}$ fertilization, there were three $\mathrm{N}$ treatments in 2002-03: $\mathrm{N}_{\mathrm{S}}, \mathrm{N}_{\mathrm{ST}}$, and $\mathrm{N}_{\mathrm{STE}}$. The symbols $\mathrm{S}$, $\mathrm{T}$, and $\mathrm{E}_{\mathrm{E}}$ denote $\mathrm{N}$ application at sowing, at tillering, and at stem elongation, respectively. The rate of each application was $105 \mathrm{~kg} \mathrm{~N}$ $\mathrm{ha}^{-1}$. Ammonium sulfate, which is commonly used by local farmers for fertilizing in the fall or winter, was used as it is less prone to leaching than ammonium nitrate. Plot size for each $\mathrm{N}$ treatment was $12 \mathrm{~m} \times 7 \mathrm{~m}$.

In 2003-04, there were $6 \mathrm{~N}$ treatments: $\mathrm{N}_{0}$ (no $\mathrm{N}$ control), $\mathrm{N}_{\mathrm{S}}, \mathrm{N}_{\mathrm{T}}, \mathrm{N}_{\mathrm{ST}}, \mathrm{N}_{\mathrm{EH}}(\mathrm{N}$ applied at stem elongation and at heading, respectively) and $\mathrm{N}_{\mathrm{STEH}}$. Plot size for each $\mathrm{N}$ treatment was $22 \mathrm{~m} \times 6 \mathrm{~m}$.

\section{Trial Management and Data Collection}

Sowing was carried out in mid-November, at rates of 180 $\mathrm{kg} \mathrm{ha}^{-1}$ for wheat and $160 \mathrm{~kg} \mathrm{ha}^{-1}$ for barley. The bread wheat variety 'Sham 4' and the 6-row barley variety 'Rihane' were used. At sowing, $120 \mathrm{~kg} \mathrm{ha}^{-1}$ of $\mathrm{P}_{2} \mathrm{O}_{5}$ as triple superphosphate was applied to all treatments in both years. In February2004, the herbicide '2,4 D + MCPA (4-cholro-2methlyphenoxyacetic acid') was sprayed at a rate of $21 \mathrm{ha}^{-1}$ to control broad-leaf weeds. At end of March 2004, a systemic insecticide (Dimethoate) was applied to control aphids (Cesamia cretica).

Table 1. Average Irrigation Amount and Evapo-Transpiration \% Met by Irrigation for the Different Irrigation Treatments of Wheat and Barley in 2004

\begin{tabular}{|c|c|c|c|c|}
\hline \multirow[b]{2}{*}{ Irrigation Treatments } & \multicolumn{2}{|c|}{ Wheat } & \multicolumn{2}{|c|}{ Barley } \\
\hline & $\begin{array}{c}\text { Total Irrigation Depth } \\
\text { (mm) }\end{array}$ & $\begin{array}{c}\text { Average ET\% Met by } \\
\text { Irrigation }\end{array}$ & $\begin{array}{l}\text { Total Irrigation Depth } \\
(\mathbf{m m})\end{array}$ & $\begin{array}{c}\text { Average ET\% Met By } \\
\text { Irrigation }\end{array}$ \\
\hline $\mathrm{ID}_{1}$ & 355 & 139.6 & 361 & 145.1 \\
\hline $\mathrm{ID}_{3}$ & 310 & 122.2 & 258 & 108.4 \\
\hline $\mathrm{ID}_{5}$ & 225 & 89.6 & 214 & 87.1 \\
\hline $\mathrm{ID}_{7}$ & 153 & 61.8 & 158 & 63.9 \\
\hline $\mathrm{ID}_{9}$ & 80 & 32.6 & 110 & 44.5 \\
\hline $\mathrm{ID}_{11}$ & 44 & 17.7 & 56 & 22.4 \\
\hline
\end{tabular}


In mid-June of 2003 and $2004,1 \mathrm{~m}^{2}$ of wheat or barley was harvested manually from each treatment. The shoot biomass and grain yields were measured. The straw yield was calculated by subtracting grain yield from shoot yield, the harvest index was obtained by dividing the grain yield by the shoot yield, and the thousand-kernel weight was measured. In 2004, grain N content was determined by the Kjeldahl method [21].

\section{Data Analysis}

Analysis of variance using the GenStat Release 6.1 package was performed on all traits. Treatment means were compared using the LSD method at the 5\% significance level. Linear regression was carried out in order to determine the relationships between amount of irrigation applied with wheat and barley yields. The T test was conducted to compare the grain $\mathrm{N}$ content of irrigated versus rainfed crops of wheat and barley under different $\mathrm{N}$ treatments.

\section{RESULTS}

\section{2-03 Experiments}

In 2002-03, there was a significant irrigation by $\mathrm{N}$ interaction on grain yield in wheat (Table 2) but not on barley. Unexpectedly, wheat grain yield of the treatment $\mathrm{ID}_{6} \mathrm{~N}_{\mathrm{STE}}$ was higher than all other treatments. The different $\mathrm{N}$ treatments were not different in grain yield under $\mathrm{ID}_{2}$ and $\mathrm{ID}_{12}$, but $\mathrm{N}_{\mathrm{S}}$ gave lower yield than $\mathrm{N}_{\mathrm{ST}}$ and $\mathrm{N}_{\mathrm{STE}}$ in $\mathrm{ID}_{10}$.

Table 2. Wheat Grain Yield $\left(\mathrm{tha}^{-1}\right)$ Under Different Irrigation and $\mathrm{N}$ Treatments in 2002-03

\begin{tabular}{|c|c|c|c|c|}
\hline \multirow{2}{*}{ N Treatments } & \multicolumn{4}{|c|}{ Irrigation Treatments } \\
\hline & ID $^{\mathrm{a}}{ }_{12}$ & $\mathrm{ID}_{10}$ & $\mathrm{ID}_{6}$ & ID $_{2}$ \\
\hline $\mathrm{N}_{\mathrm{S}}{ }^{\mathrm{b}}$ & 0.65 & 1.02 & 1.16 & 0.74 \\
\hline $\mathrm{N}_{\mathrm{ST}}$ & 1.03 & 1.67 & 1.36 & 1.19 \\
\hline $\mathrm{N}_{\mathrm{STE}}$ & 1.14 & 1.69 & 2.29 & 0.98 \\
\hline $\operatorname{LSD}(0.05)$ & \multicolumn{4}{|c|}{$\begin{array}{l}=0.579 \text { between different } \mathrm{N} \text { and irrigation, } \\
=0.515 \text { in same irrigation, } \\
=0.542 \text { in same } \mathrm{N}\end{array}$} \\
\hline
\end{tabular}

${ }^{\mathrm{a}}$ Irrigation distance from the line source in meters.

${ }^{\mathrm{b}} \mathrm{N}$ applied at sowing $\left(\mathrm{N}_{\mathrm{S}}\right)$, at tillering $\left(\mathrm{N}_{\mathrm{T}}\right)$, and at stem elongation $\left(\mathrm{N}_{\mathrm{E}}\right)$.

Grain yield and harvest index were unexpectedly low under the high rainfall received in the season (Table 3 ). There were significant differences in yields, harvest index and thousand-kernel weight between the irrigation treatments in wheat. $\mathrm{ID}_{6}$ produced the largest wheat grain yield $(1.6 \mathrm{t}$ $\mathrm{ha}^{-1}$ ), which was more than those in $\mathrm{ID}_{2}$ and $\mathrm{ID}_{12}$. Though lodging was not measured, visual judgment could easily point out that there was much more lodging under $\mathrm{ID}_{2}$ than $\mathrm{ID}_{6}$. Unlike grain yield, the highest straw yield was obtained under $\mathrm{ID}_{2}$, which was more than those in $\mathrm{ID}_{10}$ and $\mathrm{ID}_{12}$. $\mathrm{ID}_{10}$ gave the highest harvest index (24.6\%), which was higher than those in $\mathrm{ID}_{12}$ and $\mathrm{ID}_{2}$. Thousand-kernel weight was lower in $\mathrm{ID}_{12}$ than in the other three irrigation treatments.

Regarding barley, irrigation had significant effects only on grain yield and harvest index (Table 3). Unlike that of wheat, $\mathrm{ID}_{6}$ gave similar grain yield as $\mathrm{ID}_{2}$ and $\mathrm{ID}_{10}$, but higher yield than $\mathrm{ID}_{12}$. Like grain yield, the harvest index of $\mathrm{ID}_{12}$ was lower than the other three irrigation treatments, which were non-significantly different from each other.

Table 3. Average Grain and Straw Yield, Harvest Index, and Thousand-Kernel Weight of Wheat and Barley Under Different Irrigation Treatments Over All N Levels in 2002-03

\begin{tabular}{|c|c|c|c|c|}
\hline $\begin{array}{l}\text { Irrigation } \\
\text { Treatments }\end{array}$ & $\begin{array}{l}\text { Grain } \\
\text { Yield } \\
\left(\mathrm{t} \mathrm{ha}^{-1}\right)\end{array}$ & $\begin{array}{c}\text { Straw } \\
\text { Yield } \\
\left(\mathrm{t} \mathrm{ha}^{-1}\right)\end{array}$ & $\begin{array}{c}\text { Harvest } \\
\text { Index } \\
(\%)\end{array}$ & $\begin{array}{l}\text { 1000-Kernel } \\
\text { wt. (g) }\end{array}$ \\
\hline \multicolumn{5}{|l|}{ Wheat } \\
\hline $\mathrm{ID}_{12}{ }^{\mathrm{a}}$ & 0.94 & 4.46 & 17.4 & 37.5 \\
\hline $\mathrm{ID}_{10}$ & 1.46 & 4.41 & 24.6 & 44.6 \\
\hline $\mathrm{ID}_{6}$ & 1.60 & 5.29 & 22.8 & 45.9 \\
\hline $\mathrm{ID}_{2}$ & 0.97 & 6.29 & 13.2 & 44.9 \\
\hline Mean & 1.24 & 5.11 & 19.5 & 43.2 \\
\hline $\operatorname{LSD}(0.05)$ & 0.420 & 1.094 & 3.83 & 3.58 \\
\hline \multicolumn{5}{|l|}{ Barley } \\
\hline $\mathrm{ID}_{12}$ & 1.13 & 4.82 & 18.7 & 38.5 \\
\hline $\mathrm{ID}_{10}$ & 1.83 & 5.15 & 28.6 & 39.9 \\
\hline $\mathrm{ID}_{6}$ & 2.08 & 5.32 & 29.6 & 41.3 \\
\hline $\mathrm{ID}_{2}$ & 2.00 & 5.71 & 25.8 & 43.8 \\
\hline Mean & 1.76 & 5.25 & 25.7 & 40.9 \\
\hline $\operatorname{LSD}(0.05)$ & 0.450 & n.s. 0.971 & 7.00 & n.s. 4.24 \\
\hline
\end{tabular}

The nitrogen factor had a significant effect on fewer traits than irrigation (Table 4). $\mathrm{N}$ affected the grain yield, straw yield, and thousand-kernel weight of wheat, and the straw yield of barley. $\mathrm{N}_{\mathrm{S}}$ gave lower wheat grain yield and higher thousand-kernel weight than $\mathrm{N}_{\mathrm{ST}}$ and $\mathrm{N}_{\mathrm{STE}}$, but lower wheat straw yield than $\mathrm{N}_{\mathrm{STE}}$ only. $\mathrm{N}_{\mathrm{STE}}$ gave higher barley straw yield than $\mathrm{N}_{\mathrm{S}}$ and $\mathrm{N}_{\mathrm{ST}}$.

\section{3-04 Experiments}

In 2003-04 experiments, the irrigation-by- $\mathrm{N}$ interaction again was significant on wheat grain yield (Fig. 1). $\mathrm{N}_{\mathrm{ST}}$, which is the normal practice, was the highest yielding treatment in $\mathrm{ID}_{20}$ and $\mathrm{ID}_{11}$, but $\mathrm{N}_{\mathrm{EH}}$ gave the highest yield in the treatments receiving higher irrigation $\left(\mathrm{ID}_{9}\right.$ to $\left.\mathrm{ID}_{1}\right)$. The advantage of $\mathrm{NEH}_{\mathrm{EH}}$ was apparent in $\mathrm{ID}_{5}$ and $\mathrm{ID}_{3}$, but was not obvious in $\mathrm{ID}_{9}, \mathrm{ID}_{7}$ and $\mathrm{ID}_{1}$. $\mathrm{N}_{\text {STEH }}$ did not give higher wheat yield than $\mathrm{N}_{\mathrm{EH}}$, but yielded less than $\mathrm{N}_{\mathrm{EH}}$ in $\mathrm{ID}_{5}$ and $\mathrm{ID}_{3}$. Unlike wheat, again there was no irrigation-by- $\mathrm{N}$ interaction on barley grain yield.

Irrigation affected significantly the grain and straw yields, and the thousand-kernel weight of wheat and barley (Table 5). For wheat, $\mathrm{ID}_{1}$ gave higher grain and straw yields than the other irrigation treatments while $\mathrm{ID}_{9}$ gave higher 1000 -kernel weight than $\mathrm{ID}_{20}$ and $\mathrm{ID}_{1}$. For barley, $\mathrm{ID}_{1}$ gave higher grain yield than the other irrigation treatments except $\mathrm{ID}_{3}$, higher straw yield than the other treatments except $\mathrm{ID}_{3}$ 
Table 4. Average Grain and Straw Yield, Harvest Index, and Thousand-Kernel Weight of Wheat and Barley Under Different $N$ Treatments Over All Irrigation Levels in 2002-03

\begin{tabular}{|c|c|c|c|c|}
\hline N Treatment & $\begin{array}{c}\text { Grain } \\
\text { Yield } \\
\left(\mathrm{t} \mathrm{ha}^{-1}\right)\end{array}$ & 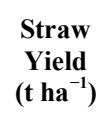 & $\begin{array}{c}\text { Harvest } \\
\text { Index } \\
(\%)\end{array}$ & $\begin{array}{l}\text { 1000-Kernel } \\
\text { wt. (g) }\end{array}$ \\
\hline \multicolumn{5}{|l|}{ Wheat } \\
\hline $\mathrm{N}_{\mathrm{S}}{ }^{\mathrm{a}}$ & 0.89 & 4.20 & 17.9 & 45.8 \\
\hline $\mathrm{N}_{\mathrm{ST}}$ & 1.31 & 5.00 & 21.1 & 42.1 \\
\hline $\mathrm{N}_{\mathrm{STE}}$ & 1.53 & 6.14 & 19.7 & 41.8 \\
\hline Mean & 1.24 & 5.11 & 19.5 & 43.3 \\
\hline LSD (0.05) & 0.372 & 1.156 & n.s. 3.33 & 2.61 \\
\hline \multicolumn{5}{|l|}{ Barley } \\
\hline $\mathrm{N}_{\mathrm{s}}$ & 1.32 & 4.50 & 23.4 & 40.4 \\
\hline $\mathrm{N}_{\mathrm{ST}}$ & 1.85 & 4.30 & 29.9 & 43.7 \\
\hline $\mathrm{N}_{\mathrm{STE}}$ & 2.10 & 6.97 & 23.8 & 38.6 \\
\hline Mean & 1.76 & 5.26 & 25.7 & 40.9 \\
\hline $\operatorname{LSD}(0.05)$ & n.s. 0.651 & 2.02 & n.s. 10.39 & n.s. 5.72 \\
\hline
\end{tabular}

and $\mathrm{ID}_{5}$, and higher 1000 -kernel weight than $\mathrm{ID}_{11}$ and $\mathrm{ID}_{20}$. Thus, wheat grain yield appeared to respond to higher irrigation than barley. The regression between grain and straw yields of wheat and barley with the irrigation depth was significantly linear at $\mathrm{P}=0.05$ for all the $\mathrm{N}$ treatments. The coefficients of determination of the linear relationships were high: 0.92 and 0.95 for wheat grain and straw yields, and 0.89 and 0.80 for barley grain and straw yields, respectively. The water use efficiency of wheat and barley dropped with the increase of irrigation amount.

As in the preliminary experiment of 2002-03, the nitrogen factor had a significant effect on fewer traits than irrigation. $\mathrm{N}$ fertilization affected wheat 1000-kernel weight and barley straw yield (Table 6). $\mathrm{N}_{\mathrm{S}}$ gave a higher 1000-kernel weight in wheat than the other $\mathrm{N}$ treatments except $\mathrm{N}_{\mathrm{ST}}$. $\mathrm{N}_{\mathrm{ST}}$ and $\mathrm{N}_{\text {STEH }}$ gave higher barley straw yield than $\mathrm{N}_{0}$.

The $\mathrm{N}$ percentages of wheat and barley grains were higher in fully-irrigated $\left(\mathrm{ID}_{1}\right)$ than in rainfed $\left(\mathrm{ID}_{20}\right)$ condition under all the $\mathrm{N}$ treatments (Fig. 2). The highest grain $\mathrm{N}$ content was obtained by the treatments $\mathrm{N}_{\mathrm{STEH}}$ and $\mathrm{N}_{\mathrm{EH}}$ (except $\mathrm{N}_{\mathrm{EH}}$ on rainfed barley). Except on rainfed barley, $\mathrm{N}_{\mathrm{EH}}$ tended to give higher grain $\mathrm{N}$ content than $\mathrm{N}_{\mathrm{ST}}$.

\section{DISCUSSION}

As far as we know, this is the first report that showed clearly that significant irrigation-by-time of $\mathrm{N}$ application interaction existed in wheat. The main cause of the interaction appeared to be different in the two years. In 2002-03, wheat plants in the treatment receiving the highest amount of irrigation lodged leading to lower wheat yield, thus the treatment receiving the next highest amount of irrigation and
Table 5. Average Grain and Straw Yield, Harvest Index, and Thousand-Kernel Weight of Wheat and Barley Under Different Irrigation Treatments Over All N Levels in 2003-04

\begin{tabular}{|c|c|c|c|c|}
\hline $\begin{array}{l}\text { Irrigation } \\
\text { Treatment }\end{array}$ & $\begin{array}{c}\text { Grain } \\
\text { Yield } \\
\left(\mathrm{t} \mathrm{ha}^{-1}\right)\end{array}$ & $\begin{array}{c}\text { Straw } \\
\text { Yield } \\
\left(\mathrm{t} \mathrm{ha}^{-1}\right)\end{array}$ & $\begin{array}{c}\text { Harvest } \\
\text { Index } \\
(\%)\end{array}$ & $\begin{array}{l}\text { 1000-Kernel } \\
\text { wt. (g) }\end{array}$ \\
\hline \multicolumn{5}{|l|}{ Wheat } \\
\hline $\mathrm{ID}_{20}{ }^{\mathrm{a}}$ & 1.2 & 2.7 & 30.5 & 26.3 \\
\hline $\mathrm{ID}_{11}$ & 1.5 & 2.9 & 33.5 & 28.5 \\
\hline $\mathrm{ID}_{9}$ & 1.9 & 3.3 & 36.2 & 29.3 \\
\hline $\mathrm{ID}_{7}$ & 2.5 & 4.6 & 35.2 & 29.2 \\
\hline $\mathrm{ID}_{5}$ & 2.8 & 5.7 & 33.8 & 28.5 \\
\hline $\mathrm{ID}_{3}$ & 3 & 6.1 & 33.2 & 28.5 \\
\hline $\mathrm{ID}_{1}$ & 3.7 & 7.5 & 33.3 & 27.0 \\
\hline Mean & 2.4 & 4.7 & 33.7 & 28.2 \\
\hline LSD (0.05) & 0.527 & 0.820 & n.s. (4.65) & 2.01 \\
\hline \multicolumn{5}{|l|}{ Barley } \\
\hline $\mathrm{ID}_{20}{ }^{\mathrm{a}}$ & 1.7 & 2.5 & 41.8 & 38.5 \\
\hline $\mathrm{ID}_{11}$ & 2.3 & 3.7 & 38.3 & 42.3 \\
\hline $\mathrm{ID}_{9}$ & 3.1 & 4.7 & 40.3 & 43.7 \\
\hline $\mathrm{ID}_{7}$ & 3.2 & 4.5 & 41.7 & 44.5 \\
\hline $\mathrm{ID}_{5}$ & 3.7 & 5.8 & 40.0 & 45.8 \\
\hline $\mathrm{ID}_{3}$ & 4.3 & 6.1 & 40.5 & 46.0 \\
\hline $\mathrm{ID}_{1}$ & 4.6 & 6.7 & 40.0 & 46.0 \\
\hline Mean & 3.3 & 4.9 & 40.4 & 43.8 \\
\hline $\operatorname{LSD}(0.05)$ & 0.805 & 1.22 & n.s. (4.95) & 2.41 \\
\hline
\end{tabular}

${ }^{a}$ Irrigation distance from the line source in meters.

the highest dose of $\mathrm{N}$ became the highest yielder. In 200304 , there was no lodging. $\mathrm{N}$ application at sowing and tillering, which is the normal farmer practice, gave the highest wheat grain yield under rainfed conditions and at the lowest irrigation levels, but $\mathrm{N}$ application at stem elongation and heading was the highest yielder at the four higher irrigation levels. As rainfall was limited around the time of stem elongation and there was no rain by the time of heading, $\mathrm{N}$ application at stem elongation and heading could not be useful under rainfed conditions or in conditions with little irrigation. However, with higher amount of irrigation, $\mathrm{N}$ applied at sowing and tillering probably was leached away by rains and irrigations, thus could not meet the need of the crop at the grain-filling stage, but $\mathrm{N}$ applied at stem elongation and heading met the demand of the crop at the right moment. Results obtained in this study on the advantages of later application of $\mathrm{N}$ (at stem elongation or heading, instead of sowing and tillering) under irrigation conditions supported the expectations or findings put forward by previous reports $[16,17,22,23]$.

Interestingly, significant irrigation-by-timing of $\mathrm{N}$ application interaction was detected in wheat but not in barley in 


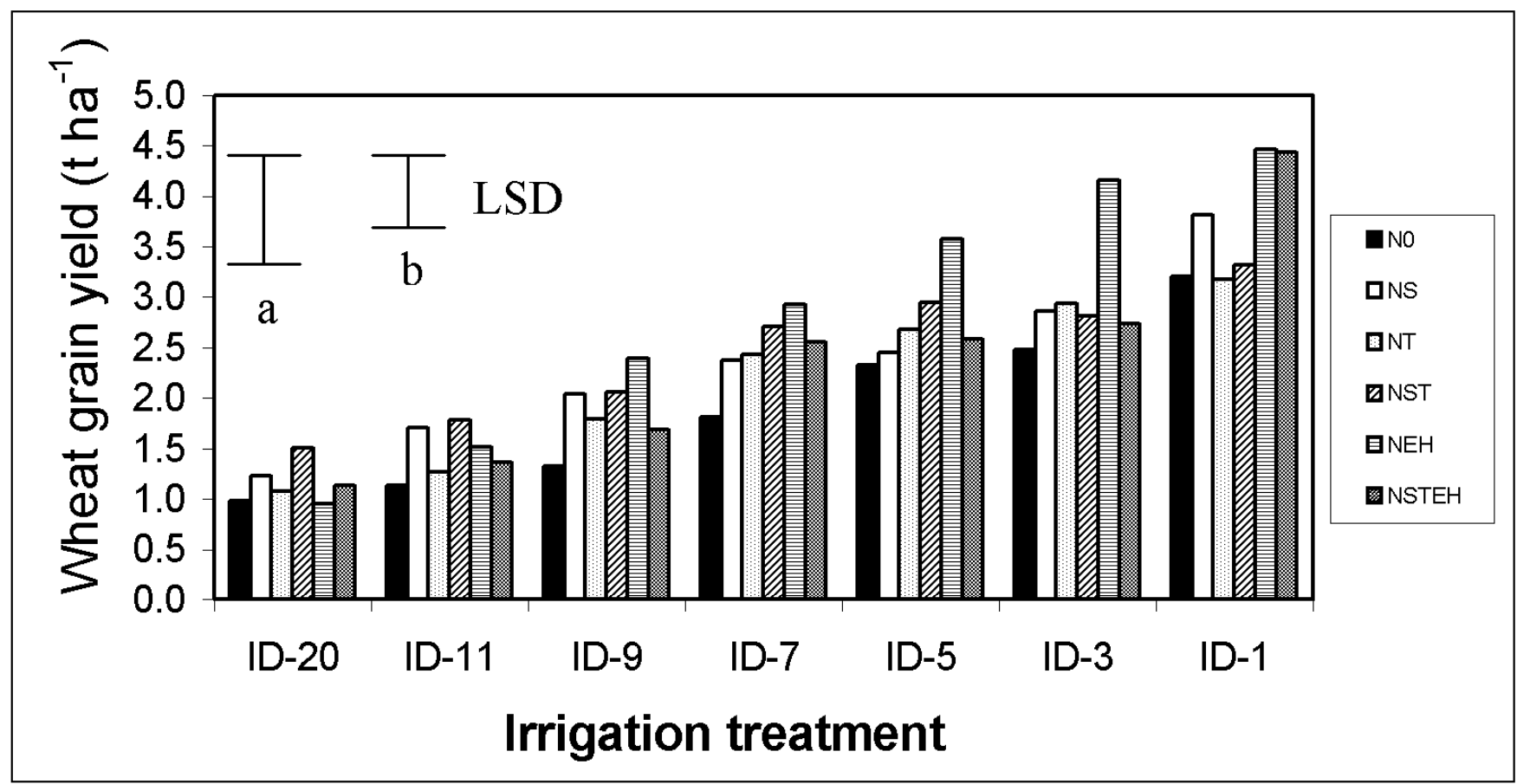

Fig. (1). Grain yield of wheat at different irrigation and nitrogen treatments in 2003-04. LSD $=0.58 ;=0.51$ in same irrigation; $=0.54$ in same $\mathrm{N}$ (Legend: 0 = Control; $\mathrm{S}=$ Sowing; $\mathrm{T}=$ Tillering; $\mathrm{E}=$ Elongation; $\mathrm{H}=$ Heading) $(\mathrm{a}=\mathrm{LSD}$ for interaction and for same level of irrigation; $\mathrm{b}=$ LSD for same level of $\mathrm{N})$.

both years of this study. The fact that two irrigations were given to wheat, but barley received irrigation only once could explain the difference in behavior between the two crops in 2002-03. However, this explanation could not hold in 2003-04 as both crops received the same numbers of irrigation with similar amount. We believe that in 2003-04 the inherent difference between wheat and barley in nitrogen use efficiency was the cause. It has been shown that wheat has a high $\mathrm{N}$ uptake after anthesis but a lower nitrogen remobilization efficiency leading to lower nitrogen use efficiency than barley and oat [24]. Thus, $\mathrm{N}$ application at stem elongation and heading would be favorable to wheat but had minor influence on barley.

This study reports a new finding that has an important practical implication. If wheat farmers are not irrigating or irrigate with minimum amount of water, they may keep their normal practice of split $\mathrm{N}$ application at sowing and tillering. However, if they irrigate their wheat crops, they better apply $\mathrm{N}$ at a later stage and split their $\mathrm{N}$ application at stem elongation and heading. For barley, split application of $\mathrm{N}$ at sowing and tillering remains as the best practice under both irrigated and non-irrigated conditions.

For irrigated wheat, clearly $\mathrm{N}_{\mathrm{EH}}$ is preferable over $\mathrm{N}_{\mathrm{STEH}}$ on the ground of economics and environmental protection. The $\mathrm{N}_{\text {STEH }}$ treatment used twice the amount of $\mathrm{N}$ fertilizer as $\mathrm{N}_{\mathrm{EH}}$ but did not lead to higher grain and straw yields, and grain $\mathrm{N}$ content. Thus, practicing $\mathrm{N}_{\mathrm{EH}}$ will save half the cost on $\mathrm{N}$ relative to $\mathrm{N}_{\text {STEH }}$. This finding was not really surprising as it is known that increased $\mathrm{N}$ fertilizer rates raise yield up to a point beyond which there is no additional response. Besides costs, environment protection is another important current issue. Farming practices are increasingly being held
Table 6. Average Grain and Straw Yield, Harvest Index, and Thousand-Kernel Weight of Wheat and Barley Under Different Nitrogen Treatments Over All Irrigation Levels in 2003-04

\begin{tabular}{|c|c|c|c|c|}
\hline N Treatment & $\begin{array}{l}\text { Grain } \\
\text { Yield } \\
\left(\mathrm{t} \mathrm{ha}^{-1}\right)\end{array}$ & $\begin{array}{l}\text { Straw } \\
\text { Yield } \\
\left(\mathrm{t} \mathrm{ha}^{-1}\right)\end{array}$ & $\begin{array}{c}\text { Harvest } \\
\text { Index } \\
(\%)\end{array}$ & $\begin{array}{l}\text { 1000- } \\
\text { Kernel } \\
\text { wt. (g) }\end{array}$ \\
\hline \multicolumn{5}{|l|}{ Wheat } \\
\hline $\mathrm{N}_{0}{ }^{\mathrm{a}}$ & 1.9 & 3.3 & 36.1 & 27.5 \\
\hline $\mathrm{N}_{\mathrm{S}}$ & 2.4 & 4.6 & 33.4 & 30.7 \\
\hline $\mathrm{N}_{\mathrm{T}}$ & 2.2 & 4.7 & 33 & 27 \\
\hline $\mathrm{N}_{\mathrm{ST}}$ & 2.4 & 5.1 & 32.6 & 29.2 \\
\hline $\mathrm{N}_{\mathrm{EH}}$ & 2.9 & 5.1 & 35.4 & 26.3 \\
\hline $\mathrm{N}_{\text {STEH }}$ & 2.4 & 5.3 & 30.4 & 27.9 \\
\hline Mean & 2.4 & 4.7 & 33.5 & 28.1 \\
\hline $\operatorname{LSD}(0.05)$ & n.s. $(0.846)$ & n.s. $(1.523)$ & n.s. (5.11) & 2.31 \\
\hline \multicolumn{5}{|l|}{ Barley } \\
\hline $\mathrm{N}_{0}{ }^{\mathrm{a}}$ & 2.4 & 4.0 & 38.0 & 43.0 \\
\hline $\mathrm{N}_{\mathrm{S}}$ & 3 & 4.2 & 40.4 & 44.7 \\
\hline $\mathrm{N}_{\mathrm{T}}$ & 3.3 & 4.7 & 42.0 & 44.6 \\
\hline $\mathrm{N}_{\mathrm{ST}}$ & 3.8 & 5.7 & 40.7 & 44.6 \\
\hline $\mathrm{N}_{\mathrm{EH}}$ & 3.4 & 4.8 & 41.3 & 43.3 \\
\hline $\mathrm{N}_{\text {STEH }}$ & 3.8 & 5.7 & 39.9 & 43.3 \\
\hline Mean & 3.3 & 4.8 & 40.3 & 43.9 \\
\hline $\operatorname{LSD}(0.05)$ & n.s. (1.05) & 1.29 & n.s. (4.54) & n.s. (2.72) \\
\hline
\end{tabular}

${ }^{\mathrm{a}} \mathrm{No} \mathrm{N}$ application $\left(\mathrm{N}_{0}\right)$; $\mathrm{N}$ applied at sowing $\left(\mathrm{N}_{\mathrm{S}}\right)$, at tillering $\left(\mathrm{N}_{\mathrm{T}}\right)$, and at stem elongation $\left(\mathrm{N}_{\mathrm{E}}\right)$ and at heading $\left(\mathrm{N}_{\mathrm{H}}\right)$. 
(a)

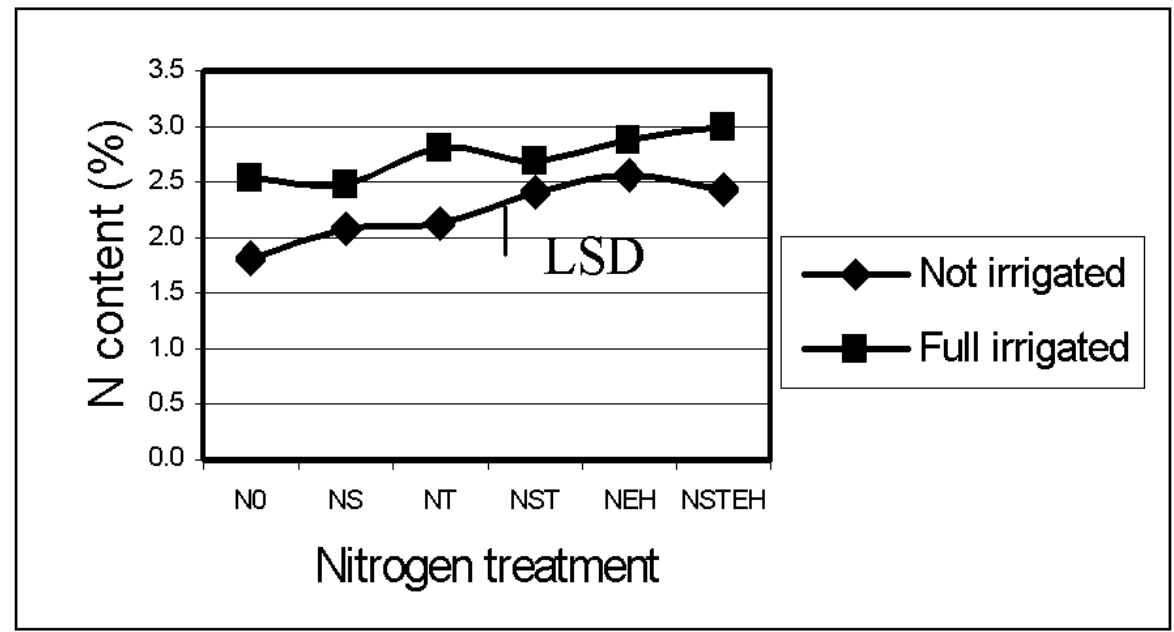

(b)

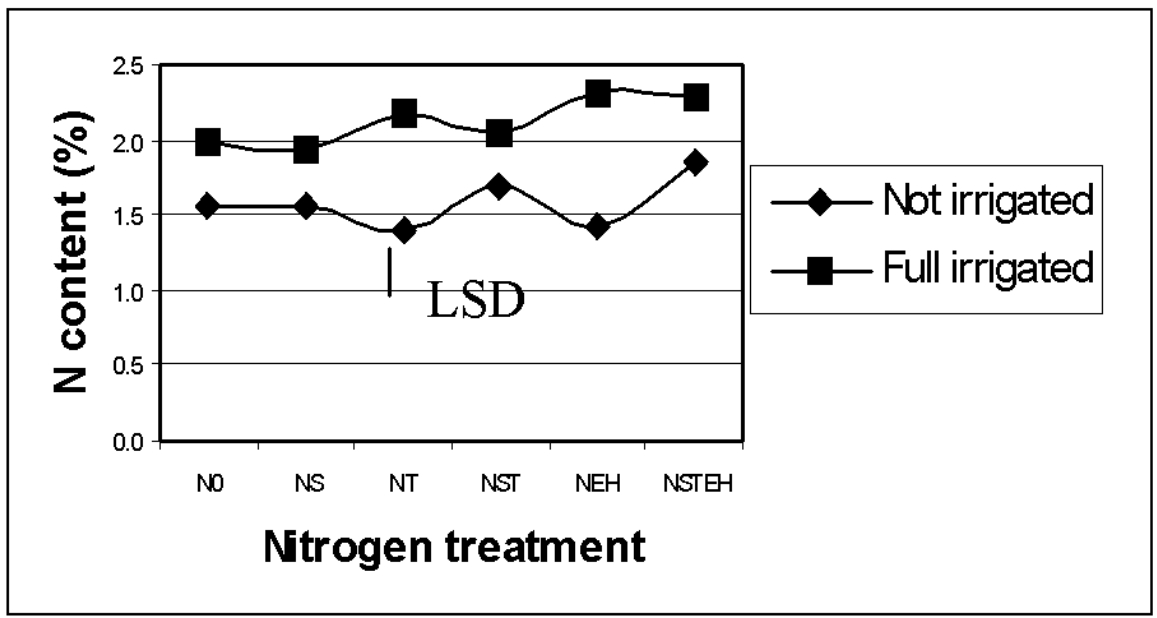

Fig. (2). Variation of the $\mathrm{N}$ content in (a) wheat and (b) barley grains of different $\mathrm{N}$ treatments in $2003-04 .\left(\mathrm{X}\right.$-axis label: ${ }_{0}=\mathrm{Control}$; $\mathrm{s}=$ Sowing; ${ }_{\mathrm{T}}=$ Tillering; $_{\mathrm{E}}=$ Elongation $_{\mathrm{H}}=$ Heading $)$.

responsible for contributing nitrate to surface and ground water. Since higher rates of $\mathrm{N}$ application generally lead to greater $\mathrm{N}$ loss $[25,3], \mathrm{N}_{\mathrm{EH}}$ is again preferable over $\mathrm{N}_{\mathrm{STEH}}$ as it is expected to cause less pollution to ground water.

Regression carried out on data collected in 2003-04 showed clearly that grain and straw yields increased linearly with higher amount of irrigation. This finding does not agree totally with that of [26], who found that yield response was not linear, but mostly curvilinear. As the response to irrigation from an initial low yield condition usually begins in a linear fashion before turning into a curvilinear response as yield is approaching the maximum, the relatively low yield of this study in comparison with those obtained by [26] most probably was the cause of the difference.

A brief explanation is warranted on the unexpected low yields and the need of irrigation despite the high precipitation in 2002-03. The country normally has a skew distribution of rainfall with $60 \%$ of the annual precipitation coming in December, January, and February. In 2002-03, the distribution was more skew than usual $(79 \%, 729 \mathrm{~mm}$ in the three winter months). As the soil is not deep $(<1 \mathrm{~m})$ at the site [19], and plants are small in the cold winters, most precipitation received in the winter months is leached and lost after saturation of the soil is reached. Unless it is a dry year, roughly the same amount of water will be stored in the soil at the end of winter no matter how high the winter precipitation is. In the absence of good rainfalls in spring and early summer, the stored water will not be able to support high yield without supplementary irrigation. In 2002-03, the lower than normal sunshine hours in the earlier part of the season, and the little amount of rainfall in April and May, plus the above normal temperatures in the two months contributed to poor yield.

\section{CONCLUSIONS}

In conclusion, there was a significant irrigation by timeof-N-application interaction in wheat grain yield, but not in barley. The normal practice of split application of $\mathrm{N}$ at sowing and tillering gave the highest wheat yield under the rainfed and lowest irrigation treatment, but split application of $\mathrm{N}$ at stem elongation and heading gave the highest yield and tended to give higher grain $\mathrm{N}$ content in the treatments receiving higher irrigation. The study suggests that wheat farmers better apply $\mathrm{N}$ at stem elongation and heading in- 
stead of at sowing and tillering if they irrigate their wheat crops. However, for barley farmers, split application of $\mathrm{N}$ at sowing and tillering remains as the best practice.

\section{ACKNOWLEDGEMENTS}

Sincere appreciation goes to Mr. Nicolas Haddad, Miss Sandra Yanni and Mr. Maroun Afram for help in the field and in the laboratory analysis, and to the Lebanese National Council of Scientific Research (LNCSR) for financial support.

\section{REFERENCES}

[1] Perrier ER, Salkini AB. Supplemental irrigation in the Near East and North Africa. Proc. of Workshop on Regional Consultation on Supplemental Irrigation, ICARDA and FAO, Rabat, Morocco, 7-9 December, 1987. Kluwer Academic Publishers, Dordrecht, 1991.

[2] Oweis T, Pala M, Ryan R. Stabilizing rainfed wheat yields with supplemental irrigation and nitrogen in a Mediterranean-type climate. Agron J 1998; 90: 672-81.

[3] Garabet S, Wood M, Ryan J. Nitrogen and water effects on wheat yield in a Mediterranean-type climate: I Growth, water-use and nitrogen accumulation. Field Crops Res 1998; 57: 309-18.

[4] Jubran I. Scheduling supplemental irrigation for wheat under varying tillage practices. MS thesis, Faculty of Agricultural and Food Sciences, American University of Beirut, Beirut, 1982.

[5] Ilbeyi A, Ustun H, Oweis T, Pala M, Benli B. Wheat water productivity and yield in a cool highland environment: Effect of early sowing with supplemental irrigation. Agric Water Manage 2006; 82: 399-410.

[6] Oweis T, Pala M, Ryan J. Management alternatives for improved durum wheat production under supplemental irrigation in Syria. Eur J Agron 1999; 11: 255-66.

[7] Panda RK, Behera SK, Kashyap PS. Effective management of irrigation water for wheat under stressed conditions. Agric Water Manage 2003; 63: 37-56.

[8] Musick JT. General guidelines for deficit irrigation management. Paper presented at the Central Plains Irrigation Short Course, Garden City, Kansas, 1994.

[9] Zhang H, Oweis T. Water-yield relations and optimal irrigation scheduling of wheat in the Mediterranean region. Agric Water Manage 1999; 38: 195-211.

[10] Harmsen K. Nitrogen fertilizer use in rainfed agriculture. Fert Res 1984; 5: 371-82.
[11] Matar A, Torrent J, Ryan J. Soil and fertilizer phosphorus and crop responses in the dryland Mediterranean zone. Adv Soil Sci 1992; 18: 81-146.

[12] Fredrick JR, Camberato JJ. Water and nitrogen effects on winter wheat in the southeastern central plain: physiological responses. Agron J 1995; 87: 527-33.

[13] Sofield IF, Wardlaw IF, Evans LT, Lee SY. Nitrogen, phosphorous and water contents during grain development and maturation in wheat. Aust J Plant Physiol 1977; 4: 799-810.

[14] Prakash KS, Sidgali T, Muhammad A. The response of sprinkler irrigated wheat to nitrogen application. Rachis 1990; 9: 25-7.

[15] Hauck RD. Nitrogen in Crop Production. American Society of Agronomy, Madison, 1984.

[16] Mossedaq F, Smith DH. Timing nitrogen application to enhance spring wheat yield in a Mediterranean climate. Agron J 1994; 86 :221-6.

[17] López-Bellido L, López-Bellido RJ, López-Bellido FJ. 2006 Fertilizer nitrogen efficiency in durum wheat under rainfed Mediterranean conditions: effect of split application. Agron J 2006; 98: 5562.

[18] Alcoz MM, Hons FM, Haby VA. Nitrogen fertilization timing effect on wheat production, nitrogen uptake efficiency, and residual soil nitrogen. Agron J 1993; 85: 1198-203.

[19] Ryan J, Musharrafieh G, Barsumian A. Soil Fertility Characterization at the Agricultural Research and Educational Center of the American University of Beirut. Publication no. 64, Faculty of Agricultural Sciences, American University of Beirut, Beirut, 1980.

[20] Bauder JW, Hanks RJ, James DW. Crop production function determination as influenced by irrigation and nitrogen fertilization using a continuous variable design. Soil Sci Soc Am J Proc 1975; 39: 1187-92.

[21] Bremner JM, Mulvaney CS. Nitrogen-total In: Page AL, et al. Ed. Methods of Soil Analysis: Part 2 Chemical and Microbiological Properties. ASA Monograph Number 9, ASA and SSSA, Madison 1982; 595-624.

[22] Papakosta DK, Gagianas AA. Nitrogen and dry matter accumulation, remobilization, and losses for Mediterranean wheat during grain filling. Agron J 1991; 87: 403-8.

[23] Palta JA, Fillery IRP. N application enhances remobilization and reduces losses of pre-anthesis $\mathrm{N}$ in wheat grown on a duplex soil. Aust J Agric Res 1995; 46: 519-31.

[24] Muurinen S, Kleemola J, Peltonen-Sainio P. Accumulation and translocation of nitrogen in spring cereal cultivars differing in nitrogen use efficiency. Agron J 2007; 99:441-9.

[25] Rasmusson DC. Barley. American Society of Agronomy, Madison, 1985.

[26] Stewart JI, Hagan RM. Functions to predict effects of crops water deficits. J Irrig Drain Div Am Soc Civ Eng 1973; 99: 421-39. 